\title{
Physicochemical and Cooking Properties of Rice (Sambha masuri) Individually Fortified with Iron, Zinc and Calcium
}

\author{
Chingakham Sima Chanu*, H. B. Shivaleela and Usha Ravindra \\ Department of Food Science and nutrition, University of Agricultural Sciences, GKVK, \\ Bangalore, Karnataka-560065, India \\ *Corresponding author
}

\section{A B S T R A C T}

\section{Keywords}

Iron, zinc, calcium fortification, parboiling, germination

\section{Article Info}

Accepted:

15 December 2019

Available Online:

20 January 2020
The present study was carried out to investigate the impact of iron, zinc and calcium fortification in rice through parboiling technique on its physicochemical properties. Rough rice were fortified in four different treatments where treatment 1 and 2 involved soaking and steaming at different temperature and duration, whereas, treatment 3 and 4 included germination as a part of fortification in addition to soaking and steaming. The results revealed significant differences in physical and cooking properties of fortified rice among the treatments. The fortified rice took longer cooking time with least cooking time in germinated fortified brown rice in treatment 3 and 4, however, germinated rice had higher gruel solid loss. All the fortified rice had soft gel consistency. A positive and a significant correlation was established between the cooking time and water uptake ratio as well as with the volume expansion ratio and elongation ratio indicating desirable traits of volume changed in cooked rice with increased in lengthwise. It was concluded that iron, zinc and calcium salts did not have impact on physicochemical changes and it was feasible to fortify rice with these micronutrients through parboiling technique.

\section{Introduction}

Rice (Oryzae sativa L.) is the staple food for 65 percent of India's population. It is mainly consumed and produced in Asian and African countries. Fortification of micronutrients in staple foods is one of the most effective, scalable, affordable, and sustainable ways to address micronutrient malnutrition. Food fortification refers to adding small amounts of vital micronutrients to foods. Fortification means deliberately increasing the content of essential micronutrients in a food so as to improve the nutritional quality of food and to provide public health benefit with minimal risk to health (FSSAI, 2018). Iron and zinc deficiency in all aged group dominates the level of malnutrition in world as well as India. 
A survey conducted by National Health Family Survey (NFHS-4) in 2015-16 confirmed 58 per cent of children, 53.2 per cent of non-pregnant woman aged 15-49 years, 50.4 per cent of pregnant women and 22.7 per cent of adult men are anaemic (Anon., 2016). Around 40 per cent of Indian children suffer from zinc deficiency (Akhtar, 2013). Calcium deficiency is another twin nutritional problem occurred usually with vitamin D deficiency. Calcium along with phosphorous is required for bone growth and metabolism. Vitamin D and Calcium deficiency induces osteoporosis. The primary calcium deficiency leads to hyperthyroidism (Harinarayan and Akhila, 2019). Mass fortification or target fortification of micronutrients in staple foods can be employed in social safety net programmes to reduce the micronutrient malnutrition. Till today, the fortification of rice with micronutrients is being done through extrusion, coating, dusting and spraying method. Fortification of micronutrients through parboiling techniques can be alternative to the mentioned techniques of fortification as parboiling can reduce loss of nutrients during washing. Parboiling of rice is a hydrothermal treatment where irreversible swelling and fusion of starch takes place. In parboiling of rough rice the crystalline form of starch present in the paddy grain is changed into amorphous form (Taghinezhad et al., 2016). It involves soaking in hot or cold water followed by steaming or thermal treatment to complete gelatinization, dehydration or drying to moisture content appropriate for milling (Oil et al., 2014). Parboiled rice is more preferred by health sensitive consumers due to its better nutritional properties compared to regular rice (Oil et al., 2014). Germination is another method of increasing the nutrient content specially zinc, calcium and iron. Germination could increase crude protein, niacin and free amino acids, reducing sugar and alpha tocopherol (Sutharut and Sudarat,
2012). It could enhance generation of bioactive compounds such as gama butyric acid (Sutharut and Sudarat, 2012) by activating the dormant enzymes in the rice grain. Therefore, combination of parboiling with germination can be a new method to fortify rice with minerals. Proper selection of fortificants and methods of fortification is highly required. In India, FSSAI has approved Ferric pyrophosphate and Sodium Iron (III) Ethylene diamine tetra Acetate, Trihydrate (Sodium federate-Na $\mathrm{Fe}$ EDTA) for iron fortification in rice and Zinc Oxide $(\mathrm{ZnO})$ for zinc fortification in rice (FSSAI, 2016). Rice is not a good source of calcium in both polished and unpolished rice. Calcium carbonate $\left(\mathrm{CaCO}_{3}\right)$ is a suitable calcium source and has a whitening effect. However, to achieve fortification in rice, large quantities of $\mathrm{CaCO}_{3}$ is required. There is less chance of negative effect on iron absorption by these quantities of calcium. Therefore, Calcium carbonate can be a choice of calcium fortification in rice. The quality of fortified rice also depends on its physical properties, cooking properties. With the above backgrounds and insights, a study was undertaken to evaluate the physical and cooking properties of iron, zinc and calcium fortified rice in variety Sambha masuri.

\section{Materials and Methods}

Rice variety Sambha masuri (BPT-5204) were procured from ZARS, VC farm, Mandya, University of Agricultural Sciences, Bangalore. $900 \mathrm{mg}$ of sodium iron (III) EDTA, $225 \mathrm{mg}$ of zinc oxide and $200 \mathrm{mg}$ of calcium carbonate were dissolved in $500 \mathrm{ml}$ of triple distilled water separately. Each $300 \mathrm{~g}$ of paddy rice (rough rice) of Sambha masuri were washed three times in filtered water followed by distilled water and removed the chaff, dirt and stones from the samples. The washed paddy rice was soaked separately in graded plastic beaker containing iron solution, 
zinc solution and calcium solution for 24 hours. The sample without fortificant was used as control in $\mathrm{T} 1 \mathrm{C} 0, \mathrm{~T} 2 \mathrm{C} 0, \mathrm{~T} 3 \mathrm{C} 0$ and $\mathrm{T} 4 \mathrm{C} 0$. The soaked grain was further proceed with treatments $1,2,3$ and 4 as follows:

Treatment 1: Soaking + steaming at 0.0 $\mathrm{kg} / \mathrm{cm}^{2}$ for 20 minutes (T1C0 and T1C4)

Treatment 2: Soaking + steaming at 0.5 $\mathrm{kg} / \mathrm{cm}^{2}$ for 10 minutes (T2C0 and T2C4)

Treatment 3: Soaking + germination + steaming at $0.0 \mathrm{~kg} / \mathrm{cm}^{2}$ for 20 minutes (T3C0 and $\mathrm{T} 3 \mathrm{C} 4$ )

Treatment 4: Soaking + germination + steaming at $0.5 \mathrm{~kg} / \mathrm{cm}^{2}$ for 10 minutes (T2C0 and $\mathrm{T} 2 \mathrm{C} 4$ )

\section{Physical properties}

The physical properties studied were thousand kernel weight, grain length, kernel breadth, length by breadth (L/B) ratio and bulk density of the fortified rice. Randomly selected ten rice grains were placed in vernier calliper either lengthwise or breadth wise. The cumulative length and breadth of the grain was measured and average reading was recorded.

Length by breadth ratio was obtained by dividing the length of a single grain by the corresponding breadth (Anon, 2013). One thousand fortified rice kernels from each treatment and variety were randomly selected, counted in triplicate and weight separately using electronic weighing balance to determine the 1000 kernel weight (Thomas et al., 2013). Fortified rice kernels were dropped into a $50 \mathrm{ml}$ measuring cylinder from a constant height and the volume occupied by rice samples were recorded and bulk density was calculated as $\mathrm{g} / \mathrm{ml}$ ratio (Thomas et al., 2013).

\section{Cooking time}

It was determined by the glass plate white centre method. Distilled water $(100 \mathrm{ml})$ was heated to boiling in $250 \mathrm{ml}$ glass beaker in water bath. A known quantity of rice grains $(10 \mathrm{~g})$ were dropped in boiling water after ten minutes of boiling. Cooking time was noted by pressing the cooked grain between the glass slides and the time taken for disappearance of opaque core of rice grains was taken as cooking time (Thomas et al., 2013). Minimum cooking time is the time when at least ninety per cent of the pressed grains no longer exhibited opaque or uncooked centers. Optimum cooking time equals the minimum cooking time plus two minutes.

\section{Water uptake ratio}

Two grams of whole rice kernels were cooked in $20 \mathrm{ml}$ distilled water for a minimum cooking time in a boiling water bath. The contents were drained after cooling down and the superficial water present in cooked rice was removed by pressing the samples between filter paper. The cooked samples were then weighed accurately and the water uptake ratio was calculated as the ratio of final cooked weighed to uncooked weight (Oko et al., 2012, Thomas et al., 2013).

\section{Water uptake ratio}

$$
=\frac{\text { Weight of cooked rice }}{\text { Weight of uncooked rice }}
$$

\section{Gruel solid loss (GSL)}

It was evaluated by drying an aliquot of cooking water in a tarred petridish to evaporate the cooking water as steam (Oko et al., 2012). The solid obtained after drying was calculated as the percentage of gruel solid loss. 
Grain elongation ratio (ER) and Volume expansion ratio (VER)

Elongation ratio was determined by dividing the cumulative length of ten cooked rice kernels by the length of ten uncooked rice kernels and the result was calculated as grain elongation ratio (Oko et al., 2012). The volume expansion ratio was determined as the ratio of final increased in volume of cooked rice to the volume increased in uncooked rice (Eram et al., 2014).

\section{Alkali spreading value}

Gelatinization temperature was indicated by alkali spreading value (Little et al., 1958). The degree of spreading of individual rice kernel in a weak alkali solution $(1.7 \% \mathrm{KOH})$ at room temperature $\left(27-30^{\circ} \mathrm{C}\right)$ was evaluated on a seven point numerical scale (Anon, 2013). Ten intact individual rice kernels were placed on a petridish. Fifteen $\mathrm{ml}$ of $1.7 \% \mathrm{KOH}$ was added to the petridish. Rice kernels were carefully separated from each other and incubated at 27$30^{\circ} \mathrm{C}$ for 23 hours to allow proper spreading of the rice kernels. 7 point numerical scale was used to determine the extent of swollen of the grains.

\section{Gel consistency}

Hundred $\mathrm{mg}$ of rice flour was taken in a test tube. $0.2 \mathrm{ml}$ of ethanol containing $0.25 \%$ thymol blue was added to the test tube containing rice flour. Then, $2.0 \mathrm{ml}$ of $0.2 \mathrm{~N}$ of $\mathrm{KOH}$ was again added to the test tubes and kept in boiling water bath for eight minutes.

The test tubes were removed from the water bath, cooled, mixed well and kept in ice bath for twenty minutes. Later the test tubes were laid horizontally for one hour and measurements were taken using the graph paper. Gel consistency of the rice varieties were classified based on the gel length as hard (less than $35 \mathrm{~mm}$ and $36-40 \mathrm{~mm}$ ), medium $(41-60 \mathrm{~mm}$ ) and soft (over $60 \mathrm{~mm}$ ) (Anon, 2013).

\section{Statistical analysis}

Data was analyzed using factorial completely randomized design (FCRD) using the OPSTAT software. Significance between the values was detected by Duncan's multiple range tests and was evaluated at significant level of 0.01 and 0.05 . Pearson correlation coefficient was performed to know the relationship between physical and cooking properties.

\section{Results and Discussion}

The present investigation was carried out to study the physic-chemical properties of fortified rice in variety Sambha masuri. It includes physical and cooking properties and the results are presented in following subheadings.

\section{Physical dimensions}

Physical dimensions such as 1000 kernel weight, bulk density, kernel length and breadth, length breadth ratio are presented in Table 1. Significant differences were found between the treatments in all physical parameters except kernel breadth and length breadth ratio $(\mathrm{p}<0.01)$. There was no significant difference in physical characteristics between unfortified and fortified rice. The highest 1000 kernel weight of the grain $(12.77 \mathrm{~g})$ was found in zinc fortified rice of treatment 1 which was not statistically different from the unfortified $(12.55 \mathrm{~g})$, iron $(12.75 \mathrm{~g})$ and calcium fortified rice $(12.55 \mathrm{~g})$ of the same treatment where soaking and steaming for 20 minutes was performed to fortify rice. The lowest 1000 kernel weight was observed in fortified rice of treatment $3(11.25 \mathrm{~g}$ to $11.36 \mathrm{~g})$ where 
soaking, germination and steaming for 20 minutes was done as a part of fortification process. The 1000 kernel weight in unfortified and fortified rice in treatment 2 and 4 were 12.09 to $12.17 \mathrm{~g}$ and 12.31 to $12.46 \mathrm{~g}$ respectively. There was not much difference in bulk density of the fortified rice between the treatments and ranged between $0.72 \mathrm{~g} / \mathrm{ml}$ to $0.75 \mathrm{~g} / \mathrm{ml}$ respectively. Kernel length of the fortified rice kernel was over $6.0 \mathrm{~mm}$ in all the treatments and fortified rice. Fortified rice of treatment 1 recorded the kernel length of 6.00 $\mathrm{mm}$ and the highest was observed in treatment $2(6.10 \mathrm{~mm})$. Kernel length of fortified rice in treatment 3 and 4 ranged from 6.05 to 6.07 $\mathrm{mm}$. According to kernel length, all the fortified rice of Sambha masuri was found to be medium grain (Anon, 2013). There was no significant difference in kernel breadth of fortified rice in all treatments and ranged from 2.00 to $2.06 \mathrm{~mm}$. The length breadth ratio of the fortified rice was between 2.94 to 3.01 and there was no significant difference between the treatments. According to the grain dimension (kernel length-breadth ratio), the fortified rice of all treatments of this variety was medium grain shape (Anon, 2013). Length, shape and weight are important to determine the size of the grain whereas a ratio of length-breadth is required to know the types of grain shape. These observations were on par with the findings of Hiremath and Kasturiba (2018) and Prakash et al., (2019). Bulk density is an important parameter for storage quality as well as to indicate purity of the grain because presence of light foreign materials reduces density and purity of the grain (Prakash et al., 2019). Our result was on par with Hiremath and Kasturiba (2018) but had higher value than those reported by Prakash et al., (2019) and also suggested that bulk density depends on grain type, grain shape and dimensional characteristics (Pandey et al., 2016). Among the treatments, fortified germinated brown rice (treatment 3 and 4) had lower bulk density compared to fortified non- germinated brown rice (treatment 1 and 2). This may be attributed to leaching out of solids during germination (Hiremath and Kasturiba, 2018).

\section{Cooking properties}

The cooking properties of fortified brown rice are presented in Table 2. Cooking properties of rice is very important as it determines the eating quality of rice and consumer's acceptance in the market. Cooking characteristics of iron, zinc and calcium fortified parboiled rice is required to know its acceptance level in the market Significant differences were exhibited between the treatments in all cooking properties except expansion ratio. However, the cooking properties were not significantly different between the types of fortified rice. There was no significant effect of treatments to the types of fortified rice in exhibiting the cooking properties.

\section{Cooking time}

Optimum cooking was recorded maximum in fortified and unfortified rice of treatment 2 (32.20, 32.33, 32.30, 32.37 minutes) followed by treatment $1(30.93,30.93,31.00,31.93$ minutes). The fortified rice of treatment 3 took shortest time $(26.67,27.00,26.67,26.33$ minutes) to cook than the rest of the treatment. The fortified rice in treatment 4 had the optimum cooking time of 28.00 to 28.33 minutes. These results were consistent with the reported studies (Zohoun et al., 2018 and Prakash et al., 2019). Many literatures suggested longer cooking time in parboiled rice than the non-parboiled rice (Oko et al., 2012 and Pandey et al., 2016). In this study also brown rice fortified through parboiling technique took longer time to cook. This may be due to fibrous bran layer present in kernel surface of the fortified brown rice (Pandey et al., 2016). Germinated fortified brown rice 
(treatment 3 and 4) took lesser time to cook compared to non-germinated fortified brown rice (treatment 1 and 2 ) in all variety in this study. The possible reason behind this difference in cooking time may be due to germination before parboiling as germination creates pores in the rice kernels leading to easy diffusion of water during cooking as well as outer layer of the kernel becomes softened resulting in lesser time to cook (Patil and Khan 2012). The same author also mentioned that germinated brown rice was easier to cook as it could be cooked at lower gelatinization temperature compared to brown rice.

\section{Water uptake ratio}

Water uptake ratio of unfortified (2.93), iron (2.94), zinc (2.93) and calcium (2.91) fortified rice of Sambha masuri in treatment 2 had higher value than the other treatments. The lowest water uptake ratio was recorded in iron, zinc and calcium fortified and unfortified rice of treatment 3 with the WUR value of 2.47 , $2.48,2.49$ and 2.49 respectively. The fortified and unfortified rice of treatment 1 and 4 had the water uptake ratio between 2.75 to 2.76 and 2.57 to 2.61 , respectively. These values were comparable to previous studies such as Oko et al., (2012) where the water uptake ratio of parboiled rice was reported in the range of 1.13 to 3.35 while Fofana et al., (2011) found it to be 2.34 to 2.97 .

\section{Gruel solid loss}

Gruel solid loss affects the quality of the cooked rice. In the present study, unfortified and fortified rice of treatment 4 had the highest gruel solid loss $(3.73-3.74 \%)$ among the treatments and the lowest was recorded in fortified and unfortified rice of treatment 1 $(2.80-2.81 \%)$. The gruel solid loss of fortified rice in treatment 3 was 3.11 to 3.12 per cent and that of treatment 2 was 2.93 per cent which was statistically significant between these two treatments. The gruel solid loss was more in germinated fortified brown rice (treatment 3 and 4) compared to nongerminated brown rice (treatment 1 and 2) and the probable reason might be bursting of the grain during cooking as observed in the germinated fortified brown rice in this study.

Oko et al., (2012) and Sirisoontaralak et al., (2015) also mentioned the bursting of the grain leading to higher solid loss during cooking.

\section{Elongation ratio (ER) and Volume expansion ratio (VER)}

There was no significant difference in elongation ratio among the treatments and also among the types of fortified rice and the value ranged from 1.12 to 1.19 . Elongation ratio is another important cooking parameter to establish the cooking quality. Cooked rice expands the size upon cooking. Lengthwise expansion is a highly desirable characteristic of cooked rice as it gives finer appearance whereas girth increased is an undesirable trait due to coarse look of cooked rice (Oko et al., 2012, Thomas et al., 2013). Volume expansion ratio (VER) in Sambha masuri was significantly highest in fortified and unfortified rice of treatment 2 with the value of 4.91 to 4.95 , followed by treatment 1 (4.53 to 4.54$)$ and 4 (4.05 to 4.09) and the least VER was recorded in treatment 3(3.63 to 3.65). The expansion ratio of the fortified rice was not significantly different between the treatments and ranged from1.12 to 1.19. VER was significantly lower in non-germinated fortified brown rice compared to germinated fortified brown rice. Previous literature found decrease in VER of parboiled rice in comparison to non-parboiled rice (Zohoun et al., 2018). 
Table.1 Physical properties of fortified rice Sambha masuri

\begin{tabular}{|c|c|c|c|c|c|c|}
\hline Treatments & $\begin{array}{c}\text { Types of fortified } \\
\text { rice }\end{array}$ & $\begin{array}{c}1000 \\
\text { kernel } \\
\text { weight }(\mathrm{g})\end{array}$ & $\begin{array}{c}\text { Bulk } \\
\text { density } \\
(\mathrm{g} / \mathrm{ml})\end{array}$ & $\begin{array}{c}\text { Kernel } \\
\text { length } \\
(\mathrm{mm})\end{array}$ & $\begin{array}{l}\text { Kernel } \\
\text { breadth } \\
(\mathbf{m m})\end{array}$ & $\begin{array}{c}\text { Length } \\
\text { breadth } \\
\text { ratio }\end{array}$ \\
\hline \multirow{4}{*}{$\begin{array}{c}\text { Soaking }+ \\
\text { Steaming }(20 \\
\text { minutes })\left(T_{1}\right)\end{array}$} & Unfortified & $12.55^{\mathrm{abc}}$ & $0.73^{\text {cd }}$ & $6.0^{b}$ & 2.00 & 3.00 \\
\hline & Iron fortified & $12.75^{\mathrm{ab}}$ & $0.73^{\mathrm{cd}}$ & $6.0^{b}$ & 2.00 & 3.00 \\
\hline & Zinc fortified & $12.77^{\mathrm{a}}$ & $0.74^{\mathrm{bcd}}$ & $6.0^{b}$ & 2.00 & 3.00 \\
\hline & Calcium fortified & $12.55^{\mathrm{abc}}$ & $0.74^{\mathrm{bcd}}$ & $6.0^{b}$ & 2.00 & 3.00 \\
\hline \multirow{4}{*}{$\begin{array}{c}\text { Soaking + } \\
\text { Steaming }(10 \\
\text { minutes) }\left(T_{2}\right)\end{array}$} & Unfortified & $12.09^{d}$ & $0.74^{\mathrm{bcd}}$ & $6.10^{\mathrm{a}}$ & 2.06 & 2.96 \\
\hline & Iron fortified & $12.12^{\mathrm{d}}$ & $0.74^{\mathrm{bcd}}$ & $6.10^{\mathrm{a}}$ & 2.06 & 2.96 \\
\hline & Zinc fortified & $12.17^{\mathrm{cd}}$ & $0.74^{\mathrm{bcd}}$ & $6.10^{\mathrm{a}}$ & 2.06 & 2.96 \\
\hline & Calcium fortified & $12.17^{\text {cd }}$ & $0.75^{\mathrm{ab}}$ & $6.10^{\mathrm{a}}$ & 2.05 & 2.97 \\
\hline \multirow{4}{*}{$\begin{array}{c}\text { Soaking }+ \\
\text { germination }+ \\
\text { Steaming }(20 \\
\text { minutes) }\left(\mathbf{T}_{3}\right)\end{array}$} & Unfortified & $11.26^{\mathrm{e}}$ & $0.74^{\mathrm{bcd}}$ & $6.05^{\mathrm{ab}}$ & 2.02 & 2.99 \\
\hline & Iron fortified & $11.29^{\mathrm{e}}$ & $0.74^{\text {bcd }}$ & $6.06^{\mathrm{ab}}$ & 2.03 & 3.00 \\
\hline & Zinc fortified & $11.36^{\mathrm{e}}$ & $0.74^{\text {bcd }}$ & $6.06^{\mathrm{ab}}$ & 2.03 & 2.96 \\
\hline & Calcium fortified & $11.25^{\mathrm{e}}$ & $0.74^{b c d}$ & $6.06^{\mathrm{ab}}$ & 2.05 & 2.94 \\
\hline \multirow{4}{*}{$\begin{array}{c}\text { Soaking }+ \\
\text { germination }+ \\
\text { Steaming }(10 \\
\text { minutes) }\left(\mathbf{T}_{4}\right)\end{array}$} & Unfortified & $12.31^{\mathrm{bcd}}$ & $0.72^{d}$ & $6.05^{\mathrm{ab}}$ & 2.01 & 3.01 \\
\hline & Iron fortified & $12.37^{\mathrm{bcd}}$ & $0.73^{\mathrm{cd}}$ & $6.06^{\mathrm{ab}}$ & 2.02 & 3.00 \\
\hline & Zinc fortified & $12.46^{\mathrm{abc}}$ & $0.73^{\mathrm{cd}}$ & $6.07^{\mathrm{ab}}$ & 2.03 & 2.98 \\
\hline & Calcium fortified & $12.42^{\mathrm{abc}}$ & $0.73^{\mathrm{cd}}$ & $6.07^{\mathrm{ab}}$ & 2.03 & 2.98 \\
\hline \multicolumn{2}{|c|}{ Treatment (A) } & & - & - & & \\
\hline \multicolumn{2}{|c|}{ F value } & $* *$ & $* *$ & $* *$ & NS & $* *$ \\
\hline \multicolumn{2}{|c|}{ SEm \pm} & 0.044 & 0.002 & 0.006 & 0.006 & 0.010 \\
\hline \multicolumn{2}{|c|}{ CD at $1 \%$} & 0.122 & 0.006 & 0.018 & - & 0.029 \\
\hline \multicolumn{7}{|c|}{ Types of fortified rice (B) } \\
\hline \multicolumn{2}{|c|}{ F value } & NS & NS & NS & NS & NS \\
\hline \multicolumn{2}{|c|}{ SEm \pm} & 0.050 & 0.002 & 0.007 & 0.007 & 0.011 \\
\hline \multicolumn{2}{|c|}{ CD at $1 \%$} & - & - & - & - & - \\
\hline \multicolumn{7}{|c|}{$\mathbf{A} \times \mathbf{B}$} \\
\hline \multicolumn{2}{|c|}{ F value } & NS & NS & NS & NS & NS \\
\hline \multicolumn{2}{|c|}{ SEm \pm} & 0.099 & 0.005 & 0.014 & 0.013 & 0.023 \\
\hline \multicolumn{2}{|c|}{ CD at $1 \%$} & & - & - & - & \\
\hline
\end{tabular}

** Significant at $(\mathrm{P}<0.01)$, NS-Non significant

Notes: Means in the same column followed by different superscript letters differ significantly 
Table.2 Cooking properties of fortified rice Sambha masuri

\begin{tabular}{|c|c|c|c|c|c|c|}
\hline Treatments & $\begin{array}{c}\text { Types of fortified } \\
\text { rice }\end{array}$ & $\begin{array}{l}\text { OCT } \\
\text { (Min) }\end{array}$ & WUR & GSL (\%) & VER & ER \\
\hline \multirow{4}{*}{$\begin{array}{c}\text { Soaking }+ \\
\text { Steaming }(20 \\
\text { minutes) }\left(T_{1}\right)\end{array}$} & Unfortified & $30.93^{b}$ & $2.77^{\mathrm{ab}}$ & $2.81^{\mathrm{c}}$ & $4.53^{\mathrm{b}}$ & 1.14 \\
\hline & Iron fortified & $30.93^{b}$ & $2.76^{\mathrm{ab}}$ & $2.81^{\mathrm{c}}$ & $4.55^{\mathrm{b}}$ & 1.16 \\
\hline & Zinc fortified & $31.00^{\mathrm{b}}$ & $2.76^{\mathrm{ab}}$ & $2.81^{\mathrm{c}}$ & $4.53^{b}$ & 1.13 \\
\hline & Calcium fortified & $31.93^{\mathrm{ab}}$ & $2.77^{\mathrm{ab}}$ & $2.80^{\mathrm{c}}$ & $4.54^{\mathrm{b}}$ & 1.12 \\
\hline \multirow{4}{*}{$\begin{array}{c}\text { Soaking }+ \\
\text { Steaming }(10 \\
\text { minutes) }\left(T_{2}\right)\end{array}$} & Unfortified & $32.20^{\mathrm{a}}$ & $2.93^{\mathrm{a}}$ & $2.93^{\mathrm{c}}$ & $4.92^{\mathrm{a}}$ & 1.17 \\
\hline & Iron fortified & $32.33^{\mathrm{a}}$ & $2.94^{\mathrm{a}}$ & $2.93^{\mathrm{c}}$ & $4.91^{\mathrm{a}}$ & 1.18 \\
\hline & Zinc fortified & $32.30^{\mathrm{a}}$ & $2.93^{\mathrm{a}}$ & $2.93^{c}$ & $4.94^{\mathrm{a}}$ & 1.18 \\
\hline & Calcium fortified & $32.37^{\mathrm{a}}$ & $2.91^{\mathrm{a}}$ & $2.93^{\mathrm{c}}$ & $4.95^{\mathrm{a}}$ & 1.19 \\
\hline \multirow{4}{*}{$\begin{array}{c}\text { Soaking }+ \\
\text { germination }+ \\
\text { Steaming }(20 \\
\text { minutes })\left(T_{3}\right)\end{array}$} & Unfortified & $26.67^{c}$ & $2.47^{c}$ & $3.11^{\mathrm{b}}$ & $3.65^{d}$ & 1.13 \\
\hline & Iron fortified & $27.00^{\mathrm{c}}$ & $2.48^{\mathrm{c}}$ & $3.12^{b}$ & $3.63^{\mathrm{d}}$ & 1.13 \\
\hline & Zinc fortified & $26.67^{c}$ & $2.49^{c}$ & $3.12^{\mathrm{b}}$ & $3.65^{d}$ & 1.13 \\
\hline & Calcium fortified & $26.33^{\mathrm{c}}$ & $2.49^{\mathrm{c}}$ & $3.12^{\mathrm{b}}$ & $3.66^{\mathrm{d}}$ & 1.13 \\
\hline \multirow{4}{*}{$\begin{array}{c}\text { Soaking }+ \\
\text { germination }+ \\
\text { Steaming }(10 \\
\text { minutes) }\left(\mathrm{T}_{4}\right)\end{array}$} & Unfortified & $28.00^{\mathrm{b}}$ & $2.61^{\mathrm{b}}$ & $3.74^{\mathrm{a}}$ & $4.09^{\mathrm{c}}$ & 1.14 \\
\hline & Iron fortified & $28.33^{b}$ & $2.59^{\mathrm{b}}$ & $3.73^{\mathrm{a}}$ & $4.05^{\mathrm{c}}$ & 1.14 \\
\hline & Zinc fortified & $28.00^{b}$ & $2.58^{\mathrm{b}}$ & $3.73^{\mathrm{a}}$ & $4.05^{c}$ & 1.15 \\
\hline & Calcium fortified & $28.33^{b}$ & $2.57^{b}$ & $3.73^{\mathrm{a}}$ & $4.05^{\mathrm{c}}$ & 1.15 \\
\hline \multicolumn{7}{|c|}{ Treatment (A) } \\
\hline \multicolumn{2}{|c|}{ F value } & $* *$ & ** & ** & ** & NS \\
\hline \multicolumn{2}{|c|}{ SEm \pm} & 0.153 & 0.017 & 0.011 & 0.015 & 0.001 \\
\hline \multicolumn{2}{|c|}{ CD at $1 \%$} & 0.438 & 0.047 & 0.030 & 0.043 & - \\
\hline \multicolumn{7}{|c|}{ Types of fortified rice (B) } \\
\hline \multicolumn{2}{|c|}{ F value } & NS & NS & NS & NS & NS \\
\hline \multicolumn{2}{|c|}{ SEm \pm} & 0.171 & 0.018 & 0.012 & 0.017 & 0.001 \\
\hline \multicolumn{2}{|c|}{ CD at $1 \%$} & - & - & - & - & - \\
\hline \multicolumn{7}{|c|}{$\mathbf{A} \times \mathbf{B}$} \\
\hline \multicolumn{2}{|c|}{ F value } & NS & NS & NS & NS & NS \\
\hline \multicolumn{2}{|c|}{ SEm \pm} & 0.342 & 0.037 & 0.024 & 0.024 & 0.001 \\
\hline \multicolumn{2}{|c|}{ CD at $1 \%$} & - & - & - & - & - \\
\hline
\end{tabular}

** Significant at $\mathrm{P}<0.01$; NS-Non-significant

Note: Means in the same column with different superscript letters differ significantly

$\mathrm{SEm} \pm$ : Standard error of mean, CD; Critical difference

OCT: Optimum Cooking Time; MCT: Minimum Cooking Time; WUR: Water Uptake ratio; GSL: Gruel Solid Loss;

VER: Volume expansion ratio; ER: Elongation Ratio; Min-minutes 
Table.3 Gelatinization and gel consistency behavior of fortified rice Sambha masuri

\begin{tabular}{|c|c|c|c|c|c|}
\hline Treatments & $\begin{array}{c}\text { Types of fortified } \\
\text { rice }\end{array}$ & $\begin{array}{l}\text { GC } \\
(\mathbf{m m})\end{array}$ & $\begin{array}{c}\text { GC } \\
\text { behavior }\end{array}$ & ASV & Category of GT \\
\hline \multirow{4}{*}{$\begin{array}{l}\text { Soaking + } \\
\text { Steaming }(20 \\
\text { minutes })\left(T_{1}\right)\end{array}$} & Unfortified & $108.00^{b}$ & Soft & $4.00^{\mathrm{b}}$ & Low intermediate \\
\hline & Iron fortified & $107.67^{b}$ & Soft & $4.10^{b}$ & Low \\
\hline & Zinc fortified & $107.33^{b}$ & Soft & $4.10^{b}$ & Low \\
\hline & Calcium fortified & $107.67^{b}$ & Soft & $4.10^{\mathrm{b}}$ & Low \\
\hline \multirow{4}{*}{$\begin{array}{l}\text { Soaking }+ \\
\text { Steaming }(10 \\
\text { minutes })\left(T_{2}\right)\end{array}$} & Unfortified & $101.00^{c}$ & Soft & $3.00^{c}$ & Intermediate \\
\hline & Iron fortified & $102.33^{c}$ & Soft & $3.00^{\mathrm{c}}$ & Intermediate \\
\hline & Zinc fortified & $103.00^{\mathrm{c}}$ & Soft & $3.00^{\mathrm{c}}$ & Intermediate \\
\hline & Calcium fortified & $102.33^{c}$ & Soft & $3.00^{\mathrm{c}}$ & Intermediate \\
\hline \multirow{4}{*}{$\begin{array}{c}\text { Soaking + } \\
\text { germination } \\
+ \text { Steaming } \\
(20 \text { minutes) } \\
\left(\mathrm{T}_{3}\right)\end{array}$} & Unfortified & $115.00^{\mathrm{a}}$ & Soft & $5.00^{\mathrm{a}}$ & Low \\
\hline & Iron fortified & $116.33^{\mathrm{a}}$ & Soft & $4.80^{\mathrm{a}}$ & Low \\
\hline & Zinc fortified & $115.00^{\mathrm{a}}$ & Soft & $4.80^{\mathrm{a}}$ & Low \\
\hline & Calcium fortified & $116.00^{\mathrm{a}}$ & Soft & $4.80^{\mathrm{a}}$ & Low \\
\hline \multirow{4}{*}{$\begin{array}{c}\text { Soaking + } \\
\text { germination } \\
\text { + Steaming } \\
(10 \text { minutes }) \\
\left(\mathrm{T}_{4}\right)\end{array}$} & Unfortified & $113.67^{\mathrm{a}}$ & Soft & $4.30^{\mathrm{b}}$ & Low \\
\hline & Iron fortified & $112.33^{\mathrm{a}}$ & Soft & $4.40^{\mathrm{b}}$ & Low \\
\hline & Zinc fortified & $113.00^{\mathrm{a}}$ & Soft & $4.40^{\mathrm{b}}$ & Low \\
\hline & Calcium fortified & $112.67^{\mathrm{a}}$ & Soft & $4.40^{\mathrm{b}}$ & Low \\
\hline \multicolumn{6}{|c|}{ Treatment (A) } \\
\hline \multicolumn{2}{|c|}{ F value } & $* *$ & & ** & \\
\hline \multicolumn{2}{|c|}{ SEm \pm} & 0.447 & & 0.039 & \\
\hline \multicolumn{2}{|c|}{ CD at $1 \%$} & 1.547 & & 0.109 & \\
\hline \multicolumn{6}{|c|}{ Types of fortified rice (B) } \\
\hline \multicolumn{2}{|c|}{ F value } & NS & & NS & \\
\hline \multicolumn{2}{|c|}{ SEm \pm} & 0.506 & & 0.043 & \\
\hline \multicolumn{2}{|c|}{ CD at $1 \%$} & - & & - & \\
\hline \multicolumn{2}{|c|}{$\mathbf{A} \times \mathbf{B}$} & & & & \\
\hline \multicolumn{2}{|c|}{$F$ value } & NS & & NS & \\
\hline \multicolumn{2}{|c|}{ SEm \pm} & 1.00 & & 0.087 & \\
\hline \multicolumn{2}{|c|}{ CD at $1 \%$} & - & & - & \\
\hline
\end{tabular}

** Significant at $\mathrm{P}<0.01$; NS-Non-significant

Note: Means in the same column with different superscript letters differ significantly GT- Gelatinization temperature; GC- Gel consistency; ASV- Alkali Spreading value 
Table.4 Correlation coefficients between the physical and cooking properties of fortified rice Sambha masuri

\begin{tabular}{|c|c|c|c|c|c|c|c|c|}
\hline & $\begin{array}{c}\text { V1 } \\
\text { (KW) }\end{array}$ & $\begin{array}{c}\text { V2 } \\
\text { (BD) }\end{array}$ & $\begin{array}{c}\mathbf{V 3} \\
\text { (L/B } \\
\text { ratio) }\end{array}$ & $\begin{array}{c}\text { V4 } \\
\text { (OCT) }\end{array}$ & $\begin{array}{c}\text { V5 } \\
\text { (WUR) }\end{array}$ & $\begin{array}{c}\text { V6 } \\
\text { (GSL) }\end{array}$ & $\begin{array}{c}\text { V7 } \\
\text { (VER) }\end{array}$ & $\begin{array}{c}\text { V8 } \\
\text { (ER) }\end{array}$ \\
\hline $\begin{array}{c}\mathbf{V 1} \\
(\mathbf{K W})\end{array}$ & 1 & -0.399 & 0.460 & $0.623^{* *}$ & $0.533^{*}$ & -0.004 & $0.615^{*}$ & 0.236 \\
\hline $\begin{array}{c}\text { V2 } \\
\text { (BD) }\end{array}$ & & 1 & $-0.523^{*}$ & 0.289 & 0.297 & $-0.626^{* *}$ & 0.242 & 0.251 \\
\hline $\begin{array}{c}\text { V3 } \\
\text { (L/B } \\
\text { ratio) }\end{array}$ & & & 1 & -0.034 & -0.173 & 0.157 & -0.110 & -0.416 \\
\hline $\begin{array}{c}\text { V4 } \\
\text { (OCT) }\end{array}$ & & & & 1 & $0.976^{* *}$ & $-0.581^{*}$ & $0.983^{* *}$ & $0.641^{* * *}$ \\
\hline $\begin{array}{c}\text { V5 } \\
\text { (WUR) }\end{array}$ & & & & & 1 & $-0.540^{*}$ & $0.993^{* *}$ & $0.749^{* *}$ \\
\hline $\begin{array}{c}\text { V6 } \\
\text { (GSL) }\end{array}$ & & & & & & 1 & -0.492 & -0.153 \\
\hline $\begin{array}{c}\text { V7 } \\
\text { (VER) }\end{array}$ & & & & & & & 1 & $0.744^{* *}$ \\
\hline $\begin{array}{c}\text { V8 } \\
\text { (ER) }\end{array}$ & & & & & & & & 1 \\
\hline
\end{tabular}

** Significant at $\mathrm{P}<0.01$; *significant at $\mathrm{P}<0.05$

$\mathrm{KW}$ : Kernel weight; BD: Bulk density; L/B ratio: Length breadth ratio

OCT: Optimum Cooking Time; MCT: Minimum Cooking Time; WUR: Water Uptake ratio; GSL: Gruel Solid Loss; VER: Volume expansion ratio; ER: Elongation Ratio; Min-minutes

\section{Gel consistency and alkali spreading value}

Gel consistency and alkali spreading value of fortified rice Sambha masuri is depicted in Table 3. Significant differences among the treatments were observed in gel length and alkali spreading value but not between the types of fortified rice. Fortified and unfortified rice of treatment 3 had the highest gel length of 115 to $116.33 \mathrm{~mm}$ and the lowest gel length was found in unfortified and fortified rice of treatment $2(101.00$ to $103.00 \mathrm{~mm})$. Unfortified and fortified rice in treatment 2 and 4 had the gel length of 101.00 to 103.00 $\mathrm{mm}$ and 112.33 to $113.67 \mathrm{~mm}$ respectively. According to gel length, all the unfortified and fortified rice of Sambha masuri were observed to have soft gel consistency. Gel consistency measures the tendency of cooked rice starch on cooling. According to gel length, cooked rice is categorized into soft, medium and hard. Soft gel consistency is associated with longer gel length whereas hard gel consistency has shorter gel length (Prakash et al., 2019). Moreover, hard gel consistency in rice leads to harden faster the cooked rice after cooking than the soft gel types. The present study found the soft gel in all fortified rice in all the varieties although the gel consistency was significantly different among the treatments. Similar finding was observed by Prakash et al., (2019) that parboiled rice had higher gel consistency with soft gel. Rice with soft gel consistency cook more tenderly and remained soft upon cooling (Oko et al., 2012 and Prakash et al., 2019). Hence, the fortified rice 
in this variety was tending to have softer cooked rice upon cooling irrespective of types of fortified rice in each treatment. Alkali spreading value is the indirect measurement of gelatinization temperature of rice to categorize the cooked rice properties since many years. Highest alkali spreading value was found in fortified and unfortified rice of treatment 3 with the value of 4.80 and 5.00 and correspondingly it had the lowest gelatinization temperature. Alkali spreading value varied from 3.00 in treatment $3,3.10$ to 3.90 in treatment $4,4.00$ to 4.10 in treatment 1 and 4.80 to 5.00 in treatment 2. According to gelatinization temperature, fortified rice in treatment 2 was observed to have intermediate gelatinization temperature and fortified rice in treatment 1,3 and 4 had low gelatinization temperature. When rice is treated with alkaline solution, disintegration of the rice grain occurs due to the changes in starch molecules present in the rice; consequently the shape of rice gets altered. Rice grain varies from no effect to completely dispersed grain (Patil and Khan, 2012). Alkali spreading value is inversely related to gelatinization temperature. Lower the alkali value higher is the gelatinization temperature. Gelatinization temperature is the temperature at which the starch molecules begin to swell in the presence of water and heat (Zohoun et al., 2018). Gelatinization temperature decreased on germination $(\mathrm{Wu}$ et al., 2013).

Similar finding was observed in the present study. Lower gelatinization temperature was observed in germinated brown rice compared to non-germinated brown rice. Similar finding was reported by $\mathrm{Wu}$ et al., (2013) and mentioned that gelatinization decreased on germination which was attributed to degradation of lipids by germination process. Treatment 2 and 4 had higher steaming temperature, thereby; starch of the fortified rice was more gelatinized resulting to higher gelatinization temperature.
Correlation coefficients among the physical and cooking properties of fortified rice

The Pearson correlation co-efficient among the physicochemical and cooking properties is presented in Table 4. 1000 kernel weight was positively and significantly correlated with optimum cooking time $(\mathrm{p}<0.01, \mathrm{r}=0.623 * *)$, water uptake ratio $\left(\mathrm{p}<0.05, \mathrm{r}=0.533^{*}\right)$ and volume expansion ratio $\left(\mathrm{p}<0.05, \mathrm{r}=0.615^{*}\right)$ whereas, bulk density was negatively and significantly correlated with length breadth ratio $\left(\mathrm{p}<0.05, \mathrm{r}=-0.523^{*}\right)$ and gruel solid loss $\left(\mathrm{p}<0.05, \mathrm{r}=-0.626^{* *}\right)$. Optimum cooking time established a highly significant and positive correlation with water uptake ratio $(\mathrm{p}<0.01$, $\left.\mathrm{r}=0.976^{* *}\right)$, volume expansion ratio $(\mathrm{p}<0.01$, $\left.\mathrm{r}=0.983^{* *}\right)$ and elongation ratio $(\mathrm{p}<0.01$, $\mathrm{r}=0.641^{* *}$ ) whereas, negative relationship was found with gruel solid loss $(\mathrm{p}<0.01, \mathrm{r}=-$ $\left.0.581^{*}\right)$. Volume expansion ratio $(\mathrm{p}<0.01$, $\left.\mathrm{r}=0.993^{* *}\right)$ and elongation ratio $(\mathrm{p}<0.01$, $\mathrm{r}=0.749^{* *}$ ) was positively and significantly correlated with water uptake ratio. Elongation ratio had a positive and significant correlation with volume expansion ratio $\left(\mathrm{r}=0.744^{* *}\right)$. Oko et al., (2012) and Rasool et al., (2015) observed the positive correlation between optimum cooking time and water uptake ratio and also with elongation ratio.

The fortified rice with higher expansion ratio had higher elongation ratio even though no significant difference was observed in elongation ratio among the treatments indicating change of volume of cooked rice and increased lengthwise and therefore, fortified rice in this study had a desirable cooking quality. Similar result was also reported by Thomas et al., (2013).

Thus iron, zinc and calcium salts did not have an effect on physicochemical properties of fortified rice. Germinated fortified brown rice had soft gel consistency and lower cooking time irrespective of types of fortified rice. It is 
therefore feasible to fortify rice with iron, zinc and calcium individually through parboiling and germination.

\section{Acknowledgement}

The authors are grateful to Department of Food science and Nutrition, University of Agricultural Sciences, UAS, GKVK, Bangalore.

\section{References}

Anonymous., 2013. Standard evaluation system for rice. International Rice Research Institute, Manilla, Phillipines.pp:44-46.

Anonymous., 2016. India Fact Sheet, National Family Health Survey (NFHS-4). International Institute for Population Sciences, Mumbai, India.p.3.

Akhtar, S., 2013. Zinc status in South Asian populations - an update. $J$ Health Popul Nutr., 31 (2):139-149.

Eram, S., Singh, A. K., Singh, A., Singh, N. K. and Singh, P. K. 2014. Physicochemcial characterization and organoleptic analysis in rice cultivars. Indian J Agric Sci., 48(6):437-445.

FSSAI (Food Safety and Standards Authority of India). 2016. Food Safety and Standards (Fortification of food) Regulation, 2016. Ministry of Health and Family Welfare, New Delhi, India, $\mathrm{p}: 1-11$.

FSSAI (Food Safety and Standards Authority of India). 2018, Food Safety and Standards (Fortification of food) Regulation, 2018. Ministry of Health and Family Welfare, New Delhi India,p:8-13.

Fofana, M., Wanvoeke, J., Manful, J., Futakuchi, K., Van Mele, P., Zossou, E. AND Bléoussi, T. M. R. 2011. Effect of improved parboiling methods on the physical and cooked grain characteristics of rice varieties in Benin. International Food Research Journal, 18: 697-703.

Harinarayan, C, V. and Akhila, H., 2019. Modern India and the tale of twin nutrient deficiency-calcium and vitamin $\mathrm{d}$-nutrition trend data 50 years-retrospect, introspect, and prospect. Frontiers in endocrinology, 10:1-22.

Hiremath, S.P. and Kasturiba, B. 2018. Effect of germination on physico-chemical properties of rice varieties. Int.J.Curr.Microbiol.App.Sci., $\quad \mathbf{7 ( 1 ) :}$ 2700-2710.

Little, R. R., Hilder, G. B. and Dawson, E. H. 1958. Differential effect of dilute alkali on 25 varieties of milled white rice. Cereal Chem., 35: 111-126.

Oko, A. O., Ubi, B. E. and Danbaba, N. 2012, Rice cooking quality and physicochemical characteristics: a comparative analysis of selected local and newly introduced rice varieties in Ebonyi State, Nigeria. Food Public Health, 2(1): 43-49.

Oli, P., Ward, R., Adhikari, B. and Torley, P. 2014. Parboiled rice: Understanding from a materials science approach. Journal of Food Engineering, 124: 173-183.

Pandey, S., Asha, M. R. and Jayadep, A. 2016. Changes in physical, cooking, textural properties and crystallinity upon iron fortification of red rice (Jyothi). $J$ Food Sci Technol., 53(2):1014-1024.

Patil, S.B. and Khan, MD, K. 2012, Some cooking properties of germinated brown rice of Indian varieties. Agric Eng Int: CIGR Journal., 14(4):156162.

Prakash, J., Megha C.P and Ramesh, D. 2019. Physico-chemical and cooking properties of selected rice varieties. Acta scientific nutritional health. 3(3): 23-30. 
Sirisoontaralak, P., Limboon, P., Jatuwong, S. and Chavanalikit, A. 2016. Effect of soaking and acidification on physicochemical properties of calcium fortified rice. J Sci Food agric., 96: 2796-2804.

Sutharut, J. And Sudarat, J. 2012. Total anthocyanin content and antioxidant activity of colored rice. Int Food Res J., 215-221.

Taghinezhad, E., Khoshtaghaza, M.H., Minaei, S., Suzuki, T., Brenner, T. 2016. Relationship Between Degree of Starch Gelatinization and Quality Attributes of Parboiled Rice During Steaming. Rice Science, 23(6): 339-344.

Thomas, R., Wan-Nadia, W. A. And Bhat, R. 2013. Physicochemical properties, proximate composition and cooking qualities of locally grown and imported rice varieties marketed in Penang, Malaysia. Int. Food Res. J., 20(3): 1345-1351.

Wu, F., Chen, H., Na Yang, N., Wang, J., Duan, X., Jin, Z. and Xu, X. 2013. Effect of germination time on physicochemical properties of brown rice flour and starch from different rice cultivars. Journal of Cereal Science, 58: 263-271.

Zohoun, E.V., Tang, E.N., Soumanou, M.M., Manful, J., Akissoe, N.H., Bigoga, J., FutakuchI, $\mathrm{K}$ and Ndindeng, S.A., 2018, Physicochemical and nutritional properties of rice as affected by parboiling steaming time and atmospreric pressure and variety. Food Sci Nutr., 6:638-652.

\section{How to cite this article:}

Chingakham Sima Chanu, H. B. Shivaleela and Usha Ravindra. 2020. Physicochemical and Cooking Properties of Rice (Sambha masuri) Individually Fortified with Iron, Zinc and Calcium. Int.J.Curr.Microbiol.App.Sci. 9(01): 315-327. doi: https://doi.org/10.20546/ijcmas.2020.901.036 